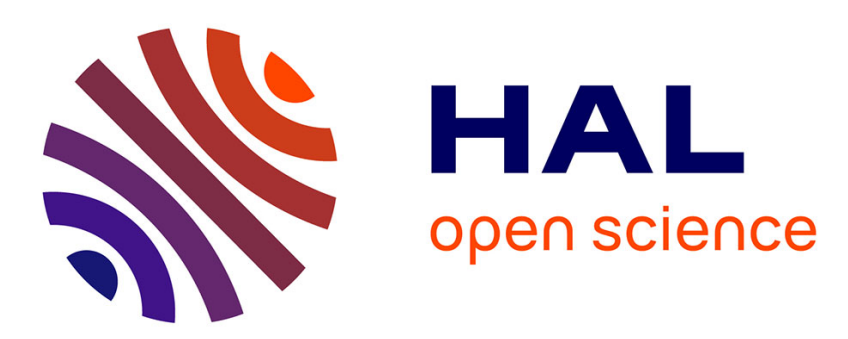

\title{
Halal on the menu?: Contested food politics and French identity in fast-food
}

Wynne Wright, Alexis Annes

\section{To cite this version:}

Wynne Wright, Alexis Annes. Halal on the menu?: Contested food politics and French identity in fast-food. Journal of Rural Studies, 2013, 32, pp.388 - 399. 10.1016/j.jrurstud.2013.08.001 . hal01564765

\section{HAL Id: hal-01564765 \\ https://hal.science/hal-01564765}

Submitted on 20 Sep 2017

HAL is a multi-disciplinary open access archive for the deposit and dissemination of scientific research documents, whether they are published or not. The documents may come from teaching and research institutions in France or abroad, or from public or private research centers.
L'archive ouverte pluridisciplinaire HAL, est destinée au dépôt et à la diffusion de documents scientifiques de niveau recherche, publiés ou non, émanant des établissements d'enseignement et de recherche français ou étrangers, des laboratoires publics ou privés. 
Halal on the Menu?: Contested Food Politics and French Identity in Fast Food

\author{
Wynne Wright* \\ Associate Professor \\ 330 B Natural Resources Bldg. \\ Michigan State University \\ East Lansing, MI 48824 \\ Tel : (517) 884-1372 \\ Email : wrightwy@anr.msu.edu
}

\author{
Alexis Annes \\ Enseignant Chercheur \\ University of Toulouse, INP-EI Purpan \\ 75 voie du TOEC \\ BP 57611 \\ 31076 Toulouse Cedex 3 \\ Tel : (33) 561153086 \\ Email :_alexis.annes@purpan.fr
}

*Corresponding author 


\title{
Halal on the Menu?: Contested Food Politics and French Identity in Fast Food
}

\begin{abstract}
France is recognized as a country whose cuisine is firmly wedded to its cultural identity, however, the common hamburger became the center of a public dialogue in 2009-2010 as the nation grappled with the meaning of halal fast food. Using content analysis of national newspapers, we analyze the French media's portrayal of the implementation of a halal hamburger menu by fast food restaurant Quick. Media framing was contentious and unsettled. We explore this discursive contest and show that the framing of responses to halalburgers ranged from those supporting acceptance of the halal menu based on free-market logic or cultural diversity, while others constructed arguments that the menu threatened French republican ideals. These frames were constructed primarily by situating them within a larger political and economic context to gain public legitimacy. We focus on both the content and strategies used by the media to assemble frames, arguing that resistance to halalburgers functions as a form of defensive gastronationalism. In this paper we show how, in their efforts to construct meaning around fast food, the media draw on gastronationalism as a political tool to reinforce French identity within national borders and, in this way, draw parameters around who is, and who is not French.
\end{abstract}

Keywords : Discourse, Fast Food, Frame Analysis, French Republican, Gastronationalism, Halal Food 


\section{Halal on the Menu?: Contested Food Politics and French Identity in Fast Food}

\section{Introduction}

France is regarded globally as a country with a proud, firmly embedded, food culture, or "culinary nationalism" (Ferguson, 2004). Evidence of this world-renown reputation was affirmed, in part, by the 2010 addition of the French multi-course gastronomic meal to the UNESCO World Intangible Heritage list. French gastronomy has also been distinguished from others based on complexity and its ability to impose itself on other cuisines as the benchmark for excellence (Poulain, 2002). Both this complexity and cultural standard fall outside the bounds of the ordinary, run-of-the meal hamburger, therefore, it is neither considered high-cuisine or worthy of protection. Yet, when the hamburger was deployed to protect sacred ideals of French republicanism, meaning and valorization of even the common, everyday hamburger was reconstructed to map onto core tenets of French identity.

In this paper, our objective is to explore the socio-political construction of food. Using the national dialogue around the halal hamburger that occurred in France in 20092010, we explore how meanings of halal foods are contested in media discourse. The debate began when the fast-food chain Quick launched an experiment to add hamburgers processed according to halal standards to its restaurant menu. Halal foods are those permitted for consumption by followers of the Islamic faith (Bergeaud-Blackler, 2006). Public response to the halal menu was varied, but most was oppositional. Resistance to the Quick experiment was scripted in national and international newspapers. "Les hamburgers halal de Quick passent mal” (Quick Halal Burgers are Hard to Swallow) (Seelow, 2010) read one newspaper headline, while another proclaimed, "Burqas?: No, Bacon Burgers are France's New Cultural Battleground" (Marquand, 2010). How does the seemingly benign topic of the menu of a fast food chain rise to the forefront of a national conversation? Why should such discursive contests be of concern to agrifood scholars? We argue that such interpretative 
disputes hold valuable insights for furthering our understanding of food boundaries, both political and cultural. They contribute to the recent call made by Campbell, Murcott, and MacKenzie (2011, p. 68) for a more rigorous investigation of the "contested cultural politics of food legitimacy."

It is well established that food and food habits are symbolic markers of culture, shaping individual and collective identities (Bell and Valentine, 1997; Bourdieu, 1984; Counihan and Van Estrick, 1997; Gabaccia, 1998; Levenstein, 1988). Food can recall our past and foretell our futures. It also delineates national boundaries, shaping social, cultural, and physical parameters (Belasco and Scranton, 2002; Boisard, 2003; Mennell, 1985; Mintz, 1986; Tebben, 2008; Watson and Caldwell, 2005). Food constitutes an important arena where national boundaries and identities are often contested and, and at times, rewritten (Allison, 1997; Ferguson, 1998; 2004; Scholliers, 2001).

Recently, DeSoucey (2010, p. 433) has emphasized the need to further explore the cultural and material dimensions of food which can be enrolled in political projects. She contends that it is through gastronationalism, or the political use of food and foodways to evoke national identities, that we can begin to map the macro dimensions of nationalism onto the micro level of identity, heritage, culture, as well as belonging and exclusion. In this way, gastronationalism draws on identity politics to legitimate particular foods and foodways, while also reaffirming national socio-political boundaries.

Employing content analysis of national newspaper discourse, we examine how meaning was constructed around halal hamburgers by the media to frame the boundaries of food legitimacy. Three frames were constructed by linking to a larger national political context. We find evidence of a frame contest whereby media actors constructed multiple frames which we refer to as the republican ideal, the free-market, and cultural diversity. In this frame contest, the republican ideal frame receives the most support. From this 
perspective, to eat - and to offer on the Quick menu - halal meat is unrepublician for many, a threat to the very notion of French citizenship. DeSoucey's concept of gastronationalism allows us to explore the socially constructed process of food power on the national stage. We show that by linking halal hamburgers to long-held notions of French identity, media frames engaged in a form of gastronationalism aligning boundaries around both French identity and food, and in this way challenging who gets to claim French citizenship.

In seeking to understand the contested framing of halal hamburgers in the French media, this study adds to the existing literature devoted to food and nationality in three ways. First, this is the first study to apply the core tenets of French Republican ideals to the study of food, allowing us to better understand food's nationalist properties. Second, this analysis reveals three competing frames of halal hamburgers demonstrating the contested cultural politics of French food legitimacy via issues of republican ideals, the free-market, and cultural diversity. Third, we show that gastronationalism does not reside solely in the domain of high-cuisine, such as DeSoucey's case of foie gras, but can be constructed to encompass and protect more quotidian foods, like the everyday fast-food hamburger. This is particularly salient given that the hamburger has not been a part of the culinary repertoire of France and because a discourse of distain for fast-food simultaneously exists in the country. The contested discourse over the role of fast-food halal hamburgers raises the question of whether French gastronomy is as unified and exceptional as is often claimed. We conclude by discussing the utility of gastronationalism as a conceptual tool to understand the politics of food battles.

\section{Background}

France is home to the largest Muslim population in Europe. It is difficult to determine precisely how many Muslims reside in France as a 1978 law prohibits the collection of data on race and ethnicity (Lamont, 2004). Popular reports suggest that Muslim immigration into 
France since the 1960s has resulted in anywhere from 3.65 to 6 million, or 4 to 11 percent of the total population (Liogier, 2012). Much of this growth stems from the settlement into France of the Maghreb population from North Africa (Algerian, Moroccan, Tunisia) and populations from the Middle East, West Africa and Turkey (Lever and Miele, 2012; Liogier, 2012).

As a result of the growing Muslim population, halal foods began to assume a new prominence in the French marketplace (Campbell, Murcott and MacKenzie, 2011; Lever and Miele, 2012). Halal foods are those ordained for consumption in the holy texts of the Koran and the Sunna (Bergeaud-Blackler, 2006). All meats are considered permissible for human consumption by these texts except swine/pork and its by-products, animals improperly slaughtered or dead before slaughtering, carnivorous animals, birds of prey, and foods not processed by ritual slaughter of animals through a process called dhabihah. Dhabihah, sometimes referred to as authentic slaughter, mandates the ritual blessing of the animal, followed by the draining of blood without pre-slaughter stunning ${ }^{1}$ (Bergeaud-Blackler, 2006; Campbell, Murcott, and MacKenzie, 2011; Lever and Miele, 2012).

During the 1990s a combination of specific economic, cultural, and political forces converged to spur halal market development (Bergeaud-Blackler, 2001, 2005, 2006). First, in a highly saturated market, the meat industry actively sought to cultivate new consumers and the growing Muslim population became an appealing target (Lever and Miele, 2012). Second, the development of halal production would not have been possible without a favorable regulatory climate. European Union (EU) legislation mandates that animals be rendered unconscious by pre-slaughter stunning, a violation of halal standards. An

\footnotetext{
${ }^{1}$ Muslim authorities are not in agreement as to the importance of stunning of the animal prior to slaughtering. Those who advocate no stunning do so based on the belief that stunning could possibly kill the animal prior to slaughter or might prevent a complete drainage of blood, rendering the meat 'haram', or forbidden. For a more complete discussion of this issue, see Lever and Miele (2012).
} 
exemption to the EU legislation, however, permits abattoirs to satisfy the Muslim requirements of halal slaughter (Lever and Miele, 2012). Lastly, religious authorities have shown little interest in halal production and the development of standards. In part, this is due to the historic segregation of Muslims and their foodways from non-Muslims. Muslims can trust that, by patronizing fellow Muslim butchers, their meat is halal (Campbell, Murcott, MacKenzie, 2011). The absence of a directive - the unwillingness of Muslim authorities to disavow its importance - coupled with the desire of Muslims to consume halal foods as an identity marker, contributes to the development of the market (Bergeaud- Blackler, 2006).

Some estimate that the halal market is valued at $€ 5.5$ billion and growing at a rate of 20 percent annually (Soeren, 2012). While controversy continues and standards and certification systems remain in flux, halal products line the shelves of small shop keepers, butcheries, fast food restaurants, such as Quick and KFC, as well as international hypermarkets, like Carrefour and Géant Casino.

The market for halal has also been influenced by growth in the restaurant sector. The French are eating outside the home more frequently (Poulain, 2008), making the demand for halal more pronounced. From 2002-2007 the fast-food sector grew by 52 percent and fullservice restaurants increased by 7 percent. Street stalls and kiosks rose by 25 percent and self-service cafeterias grew by 14 percent (Swedish Trade Council, 2009). In this light, Quick's halal hamburger is only one of many initiatives designed to respond to these changing market opportunities.

\subsection{Quick Primer}

Quick was established as a fast-food hamburger restaurant in Belgium in 1971 and moved into France in 1981. In 2007, the company was bought by French-owned, Qualium Investissement, a subsidiary of the Caisse des Dépôts et des Consignations. Caisse des Dépôts et des Consignations is a fully state-owned financial institution created in 1816 to 
rebuild the French economy on the heels of disastrous economic management during the Napoleonic empire. Its mission is to oversee the public largess through managing pension programs, social housing, social security, regional development investments, infrastructure development, and related interests that directly serve the common good. The institution describes itself and its subsidiaries as "a State-owned group at the service of the public interest and of the country's economic development. The said group fulfills public interest functions in support of the policies pursued by the State and local authorities and may engage in competitive activities" (Caisse des Dépôts et des Consignations, 2012)ㄹ." Qualium is the private equity arm of Caisse des Dépôts et des Consignations owning majority control of Quick. We draw attention to the ownership arrangement because the fact that the state is a shareholder in Quick through its investment in Qualium becomes a point of claims-making in media discourse.

In 2010, 371 Quick restaurants were operating in France (around 80 percent were franchises) making it the second largest fast-food company in the nation after the global leader, McDonalds. It controls about eight percent of the French fast-food market (Swedish Trade Council, 2009). A significant part of Quick's marketing strategy has been to distance itself from McDonalds; perhaps the biggest step to do this was taken when Quick introduced its newest menu item - the halal hamburger. The announcement incited a contentious discursive dispute that persisted for almost one year in the media.

\subsection{Halal on the Menu}

\footnotetext{
${ }^{2}$ For a more extensive corporate profile, see http://www.caissedesdepots.fr/en/home.html. and http://www.qualium-investissement.com/en-gb/qui-sommes-nous/qui-sommesnous.html.
} 
In November 2009, Quick quietly launched the sale of halal hamburgers in eight restaurants. The decision to explore this new market grew out of the initiative of the owner of a Quick franchise located in the Le Mirail district of Toulouse - an area with a large Muslim population. The trial at the Le Mirail restaurant was successful beyond all expectations, and, soonafter, Quick began experimenting with the feasibility of reproducing halalburgers in their corporate stores (Pommier, 2009). ${ }^{3}$ A total of eight restaurants were selected $^{4}$ for the trial, which, from November 2009 to May 2010, offered on their menu beef, chicken, and turkey products prepared with certified halal meat. ${ }^{5}$ According to Quick, the objective of this experiment was to assess the commercial interest of halal offerings and to determine the technical feasibility of offering both halal and non-halalburgers (Quick, 2010).

The experiment in the corporate restaurants showed a significant increase during the trial and Quick expanded the new halalburger menu to 14 additional restaurants (now a total of 22 stores nationally). ${ }^{6}$ In these restaurants, only halal hamburgers were sold, no nonhalalburgers were offered; these stores became popularly referred to as "halal Quick's". Quick contended that offering halalburgers and non-halalburgers would necessitate two different production lines which created potential for mishandling and cross-contamination, thereby threatening consumer confidence (Quick, 2010).

\section{Theoretical Background}

\footnotetext{
${ }^{3}$ Three criteria were used to select experimental restaurants: (1) a higher proportion of sales of fish burgers; (2) a lower proportion of sales of bacon hamburgers; and, (3) variations in overall hamburger sales before, during, and after Ramadan.

${ }^{4}$ Four restaurants were located in the Parisian region, one restaurant in Toulouse, one in Marseille, one in Roubaix, and one in Villeurbanne.

${ }^{5}$ The certifying body for Quick's halal meat is the nation's leading certifier, the Association Rituelle de la Grande Mosquée Lyon (ARGML). See: http://hallal.mosquee-lyon.org/. ${ }^{6}$ As of December 2012 there were 23 Quick restaurants selling halal burgers.
} 


\subsection{Food, national identity, and gastronationalism}

National identity is a collective phenomenon whereby people subject to a national political authority are, likewise, distinctive in their shared norms, values, beliefs, symbols, myths, and traditions. Its production and reproduction also rests upon a common history which collectively manifests a shared identity, occurring in concert with the construction of 'distinctiveness' and 'uniqueness' (Scholliers, 2001). It is constructed discursively through language and performed via shared practices.

Shared foods, along with their production, processing, and consumption norms, can play a part in constructing and maintaining national identity by bonding social actors and creating distinctive identities linked spatially and temporally (Belasco and Scranton, 2002; Bell and Valentine, 1997; Counihan, 2002; Counihan and Van Estrick, 1997; Gabaccia, 1998; Goody, 1997; Mennell, 1985). DeSoucey (2010, p. 434) likens the connective role of food to that of other nationalist material artifacts by positing that food and food habits provide links between individuals and their cultural past in the same way that "[n]ationalist symbols and practices such as flags and anthems" unite citizens together by creating a common identity. Food can be an agent of socialization, teaching individuals to define legitimate foods and foodways in culturally prescribed ways.

While food and foodways bind people together reinforcing group membership, they simultaneously set actors apart or perform exclusionary roles that segregate or are used to reinforce "otherness" (Bourdieu, 1984; Ferguson, 1998; Mintz and Du Bois, 2002). Food and food habits delineate "us" from "them" and, in doing so, perform the work of constructing boundaries which differentiate and segregate (Lamont, 2002; 2004). Food can unite and segregate actors racially and ethnically, as well as differentiate individuals by religion (Bynum, 1997; Gastwirt, 1974), or gender (Bordo, 1997; Van Esterik, 1997). Perhaps the most notable example is the work by Bourdieu (1984) who demonstrated that food, cultural 
habits, and tastes express complex social class relations and cultural ideologies, in this way integrating members within a class and stratifying individuals between social classes.

Likewise, Mennell (1997) concludes that food provides "civilizing” tendencies (Mennell, 1997) affiliated with status maintenance historically embedded in the process of nationbuilding.

Considerable scholarship has been directed at examining food and national identity in the French context. France enjoys an international reputation as a country in which food and food habits are believed to be exceptionally strong markers of national identity, both outside and inside its boundaries (Martigny, 2010). While food may be more or less visible in some cultures, "the French national identity is without question bound up in its culinary identification by the world. Gastronomy is seen as French and the French are seen as gastronomes" (Tebben, 2008, p. 162). Ferguson (1998, p. 6) shows that social and political gastronomic ideologies were marshaled over centuries to construct this exceptional "culinary nationalism" which has come to be regarded as "the culinary consciousness of the west." Whether it be the classic dishes that handily evoke francité or Frenchness, such as the pot-aufeu, complex cream-based sauces, or the classic foie gras, for many, France would not be French without its exalted "patrimoine culinaire" (Fantasia, 1995, p. 202).

This exalted status is affirmed by efforts to distinguish French cuisine from others in three ways: through aesthetisation - or a hedonist dimension; its role as a vector of traditional patrimony; and its refinement (Martigny, 2010; Poulain, 2008; Tebben, 2008). However, French cuisine is not "an unchanging monolith" (Martigny, 2010, p. 40). In fact, its national specificities have long been controversial. It was not until the nineteenth century that a national contour was only 'formalized' according to Ferguson (1998). But it still remains open and fluid (Martigny, 2010). One of the clearest examples is in the class dimensions and regionalism of French cuisine. 
Poulain (2002) argues that until the nineteenth century, it was difficult to speak of a singular 'French cuisine' owing to the prevalence of significant culinary diversity closely wedded to social class and regional specificities. Today, when numerating its identifying characteristics, Poulain (2002, p. 201) argues that it is its high degree of complexity and its ability to impose itself as a referent among the elites of other cultures that sets French cuisine apart. As a result, he concludes that, French national cuisine is today a combination of different regional cuisine sub-cultures, a set of "sous-culture alimentaires regionales" (Poulain, 2008, p. 175).

Others add that 'refinement' is central to French food identity. "Deciphering the Frenchness of the food requires language and narrative" as "the Frenchness of the food is hidden, accessible only to those who speak the language" (Tebben, 2008, p. 165). What makes French food distinctive is the specificities of the cooking process, the origin of the ingredients, their combination in unique dishes, their attachment to a particular terroir and ancestral 'know-how,' and/or its pairing with particular wines. Therefore, mastering French language is essential to truly appreciate French cuisine in its most nuanced subtleties as it necessitates deconstruction and diffusion via a culinary discourse (Tebben, 2008). Tebben does not speak of the role of the media in her assessment of the importance of language, yet this study shows that the media play an important role in this interpretative process.

Martigny (2010) contends that French gastronomy perpetuates national identity both within and outside French boundaries. Within French boundaries, the issue of a national cuisine refers "to a mundane nationalism, that is to say a set of routinized practices, actions and values developed by the members of a national community in order to daily perpetuate the identification relative to the nation" (author translation) (Martigny, 2010, p. 41). Outside French boundaries, "[French cuisine] allows France, through the promotion of French taste, to occupy a dominant symbolic position and illustrates the French reaction to globalization 
perceived as 'aculturing' or 'Americanizing'" (author translation) (ibid). Overall, he views French gastronomy as relating both to a set of symbolic values with positive connotations such as taste, quality, and health, as well as to a set of spatial dimensions such as the village, terroir, and countryside. These referents reinforce the important role of space and place in national identity as well as contributing to the deification of the French art de vivre (art of living).

While the above literature documents what is perceived to be causally related to the ascendency of French culinary superiority, Steinberger (2009) chronicles its descent. Where others see excellence, he contends that French cuisine is on a decline which is worrisome, not merely because it signals culinary disgrace, but because it portends the erosion of the French nation itself. To fall off the world's culinary pedestal is akin to the socio-cultural decay of the nation. The finger of blame for this decline is frequently pointed at the growing ‘invasion’ of fast-food (Fantasia, 1995; Poulain, 2002), which started in the 1980s and continued throughout the 1990s. Fast-foods physical and cultural presence symbolize for many the homogenizing, "'one-size-fits-all' approach to food" engendered by globalization (Gordon and Meunier, 2001, p. 30) and therefore, stands at odds with what others perceive to be a cuisine of culinary complexity and regional diversity. For the past 15 years, fast-food restaurants have been derisively associated with the notion of mal bouffe, or bad food, and the unwelcome Americanization of French society. Herein lies one of the many contradictions of French gastronomy, however. While the French slander fast-food, they are simultaneously staunch patrons, making fast-food a popular mode of food consumption-particularly among young people (Poulain, 2002). Fantasia (1995) argues that restaurants like McDonalds give French youth an opportunity to experience a new autonomous and liberating social space. Given the long lines outside the doors on any given evening, it is hard to deny that fast-food consumption is not well integrated in everyday French life (Poulain, 2008). 
In response to the perceived threat to French gastronomy from the forces of globalization, the French government attempted to act to officially preserve its culinary status (Gordon and Meunier, 2001). Whereas Italians reacted to the opening of a McDonalds' restaurant near the Spanish Steps in Rome in 1986 with the grassroots mobilization of the now internationally recognized Slow Food movement, the French took a more bureaucratic approach. In 1990, the French Ministry of Culture initiated the Conseil National des Arts Culinaires (National Council of Culinary Arts) with the explicit purpose to preserve traditional French restaurants and culinary traditions ${ }^{7}$. More recently, former president Nicolas Sarkozy sought induction of French gastronomy into the UNESCO World Intangible Heritage list in $2008^{8}$ (Martigny, 2010). Even though French cuisine was not ultimately admitted to the heritage list, the unique French meal, their cultural foodways, was admitted.

Clearly, this review reminds us there is no objective indicator of culinary superiority. Regardless of whether French cuisine is believed to sit atop the gastronomic hierarchy or to be tumbling downward, these competing interpretations of the distinguishing characteristics of French cuisine, along with the political projects devoted to preservation, reinforce that French gastronomy is a socially constructed process open to discursive battles that seek to garner cultural and political influence and, are, part and parcel, constitutive of the making of gastronationalism itself (DeSoucey, 2010). Gastronationalism is "a form of claims-making and a project of collective identity" which "signals the use of food production, distribution, and consumption to demarcate and sustain the emotive power of national attachment, as well as the use of national sentiments to produce and market food" (p. 433). It legitimatizes a sentiment of national exceptionalism and, according to DeSoucey, can be a fierce policy strategy on the pan-nationalist stage when used to advance national interests, such as trade

\footnotetext{
${ }^{7}$ This Council was disbanded in 1999.

${ }^{8}$ French gastronomy was not added to the UNESCO World Intangible Heritage list, instead the French meal was finally inducted. This decision on the part of UNESCO was made to distinguish French food from unique French foodways.
} 
protections (e.g., geographic indications) or exemptions. Gastronationalism "presumes that attacks (symbolic or otherwise) against a nation's food practices are assaults on heritage and culture, not just on the food item itself' (p. 433). Gastronationalism is a particularly useful platform from which to delve more deeply into the alignment of food and national identity. We see the French framing dispute over halalburgers as an example of the making of gastronationalism within national boundaries, demonstrating the constructed nature of the process and, thereby, the fragility of traditional foods to consistently serve as unchallenged markers of national identity.

\subsection{French identity and republican universalism}

Whether French food is exceptional is less a concern in this paper than is the distinctive cultural and political framework France offers from which to contemplate issues of national identity through the lens of food. While much of the western, industrialized world has embraced the spirit of multiculturalism, France has adopted a different model of integration (Jennings, 2000).

France is a nation of significant cultural and ethnic diversity, yet its politics of national identity and citizenship remain firmly rooted in republican universalist ideals inherited from the 1789 Revolution designed to put an end to the inequality-based ancien régime. Republican universalism rests upon the premise of equality through secularism which requires the distinction of public and private spheres (Akan, 2009; Béland, 2003; Schnapper, 2010). Whereas multicultural societies, such as the United States, strive toward socio-cultural and political equality through pluralism and the accommodation of cultural diversity, France attempts to achieve these goals by promoting "the supremacy of the state over religious organizations" (Roy, 2007). Citizens are viewed as abstract individuals whose private group attributes, such as gender, class, race, religion, or sexuality, can institute 
inequality (Johnstone, 2008), therefore, citizens delegate "political sovereignty to the state whose role is to define and promote the common good" (Lamont, 2004, p. 146).

French republicanism is founded on three universalist principles: liberté, égalité, and fraternité (Laborde, 2001). Liberté (freedom) refers to citizens' ability to exercise individual authority. Citizens should be able to critically assess their cultural attachments which come from the exercise of free choice, not a coercive heritage. Cultural attachments should remain private, and undisclosed in the public sphere. Through this process, égalité (equality) is achieved since personal or group attributes are not publically accommodated. Fraternité (brotherhood) becomes possible as private interests and attachments are put aside, allowing citizens to work cooperatively for the common good. Finally, laïcité, loosely referred to as political and legal secularism (Roy, 2007), solidifies these three republican ideals.

In the French context, initially it referred to the complete separation of church and state, but not just by segregating. Lä̈cité goes further to guarantee through law a neutral public sphere. Through this separation citizenship is "wholly apart from cultural identities, communal belonging, and sectarian affiliation" (Roy, 2007). Universalist principles have been advocated for more than two centuries, shaping French politics of integration and assimilation ${ }^{9}$ (Jugé and Perez, 2006). In fact, such politics often conflate French values and French citizenship: if one wants to become French, one has to adhere to this set of republican universalist ideals (Schnapper, 2010).

France's unique approach of citizenship has come under fire for years, but the last decades have witnessed a watershed of criticism (Lamont, 2004). Opponents argue that French republican universalism, while intended to achieve equality through the practice of secularism, or cultural/color-blindness, actually perpetuates these very same social problems

\footnotetext{
${ }^{9}$ Two laws anchor this exceptional political ideology. The 1905 Law of Separation of Church and State outlawed symbols of religious and other cultural identity in public. The Jules Ferry Laws of 1881/82 mandated free secular education, thereby erasing regional differences to solidify citizens (Roy, 2007).
} 
(Bertossi, 2012) by denying history or France's record of socio-cultural and political oppression of others. This critique arises from France's imperialistic legacy and this approach, it is argued, "conflates the self-determination of the autonomous subject with the subjectivity of the European white male" (Laborde, 2001, p. 21). In other words, the French public sphere has never been a neutral space, but reflects the values of the dominant race, class, gender, and religion. In this way, republican universalism is argued to be a tool to legitimize elite, white, male, Christian rule, while silencing challengers in the name of citizenship (Jugé and Perez, 2006). Initially designed to promote liberté, égalité, and fraternité, these principles more accurately deny this franchise to newcomers, critics claim. Vocal opposition to republican universalism seems to be mounting, in part due to changing demographic trends. For some this takes on accusations of racial and ethnic intolerance whereas others cite gender oppression as a consequence of the modern liberal, universalist model (Bereni, 2007; Fraisse, 1989; Landes, 1988; Scott, 1996; 2004). The predominant discourse decrying republican universalism today is by critics citing religious intolerance to followers of Islam. Roy (2007, p. 88) writes that "laïcité is clearly antireligious in practice, but it is not only or mainly anti-Islamic." But is has become an ideological lightening rod and is often at the core of discursive battles around immigration and French identity.

French sociologist Liogier (2012, p. 177) argues that an "Islamization of France" discourse has gripped the nation and has risen to a moral panic, or a "collective paranoia of Muslims." Fear and scapegoating are common reactions to the ever-present myth that Islam is taking over the country. This argument is not isolated and echoes others put forward by French (see for example Delphy, 2006 or Roy, 2005) and other scholars (see for example Lamont, 2002; 2004). The so-called "Islamic threat," to republican universalism, these authors argue, was used to legitimize new laws criminalizing ostensible religious signs, such 
as the wearing of the burqa in public spaces by Muslim women and female children's wearing of veils in public schools (Delphy, 2006; Roy, 2005), as well as the refusal to permit halal lunch options in public schools (Liogier, 2012). For Liogier (2012), such collective paranoia is an attempt to define an enemy to help make sense out of undesirable demographic trends. Lamont (2002), views such discourse as drawing symbolic boundaries between nonimmigrants and first-, second-, and even third-generation immigrants—especially those originating from Muslim countries. Moreover, she suggests that this discourse goes hand-inhand with that which emphasizes "insurmountable cultural differences" (p.391) between French citizens and Muslim immigrants. Muslim immigrants are constructed as the "other," those unable to adopt French republican ideals, but imposing their religion on French society (Delphy, 2006; Lamont, 2002). Bonnafous (1991) adds that the mass media

has been critical in perpetuating the image of Muslim immigrants as unassimilable.

\section{Methods and Data}

Our objective in analyzing the discourse of the French media was to ascertain how they constructed meaning of, or framed, Quick's introduction of halal hamburgers. Frames are cognitive schema, or mental constructs, that allow individuals to construct reality (Goffman, 1974) by filtering inputs. Where some elements are foregrounded, amplified, and accentuated, others are downplayed or neglected (Entman, 1991; Gamson and Modigliani, 1987; Gamson, 1992; Lamont and Small, 2000; Scheufele, 1999). A good deal of scholarship has applied frame analysis to the study of social phenomenon. Among the most appropriate for our purposes are in the areas of media studies and social movements. Gitlin 
(1980, p. 6), for example, applies frame analysis to the media, arguing that "frames are principles of selection, emphasis and presentation composed of little tacit theories about what exists, what happens, and what matters." We think of these "tacit theories" as claimsmaking strategies. Claims-making is an activity whereby claims are articulated to persuade an audience to share the claims-makers view of reality (Spector \& Kitsuse, 1977). Claimsmaking originates within the social problems domain whereby claims-makers package claims to construct social issues as problems worthy of public intervention. Media actors make claims by highlighting words and images to valorize some social arrangements, while devaluing others. Claims are then bundled to frame the issue at hand and direct the audience's gaze, in this way, constructing boundaries around their interpretation of reality. Media framing scholar Diana Kendall (2011, p. 210) writes that "the media do not simply mirror society, they help to shape it and to create cultural perceptions." In this way, the act of framing becomes a strategic and purposeful craft of making meaning to achieve political ends. By merely making news accessible to the public, the media may "prime" or influence the importance of certain issues (Iyengar, 1990). It may also overtly slant or bias the news to encourage the audience to accept a view of reality in line with certain political orientations (Cohen, 1963). Empirical studies from national politics (Kahn and Kenney, 2002), to human genetics research (Kitzinger and Reilly, 1997) to bioenergy development (Wright and Reid, 2011) show that "slanted news is not...the rare exception" (Entman, 2007, p. 165) the media often claim. In our case, media framing of halalburgers has political implications for infusing gastronationalism with defensive tendencies.

Before frames can aid in organizing perception, they must first align with the audience, or be perceived to be "congruent and complementary" (Snow, Rochford, Worden, Benford, 1986, p. 464). Coles (1998, p. 373), for example, argues that alignment is facilitated by drawing from or altering "elements of the dominant culture, thus incorporating 
preexisting beliefs and symbols as well as oppositional values that emerge in the course of the struggle." Snow et al (1986, p. 467) define this ideological linking strategy as frame bridging. Specifically, frame bridging is the "linkage of two or more ideologically congruent but structurally unconnected frames regarding a particular issue or problem" (Snow et al., 1986, p. 467). It attempts to inspire interest or mobilization on the part of the reader by connecting the issue to another topic in which they can relate. In our case, we will see that media actors, at times, bridged burgers to broader cultural norms and values rooted in the fabric of French republican universalism and at other times bridged burgers to free-markets, and cultural diversity.

Data for this study were derived from an interpretative content, or discourse, analysis of media accounts of the halal experiment found within three newspapers: ${ }^{10}$ Libération, LeMonde, and LeFigaro between December 2009 and September 2011. This time period was selected because an exploratory review of many media outlets revealed that this was when the halal campaign was launched and claims-making ensued. These newspapers were selected because they are considered national "opinion-leading" newspapers. Each is a daily periodical, has a well established reputation, enjoys a robust readership, and is considered to be among the frontrunners in national and international issues. There are differences, however. Libération, established in 1973, is considered to be ideologically left of center; LeMonde, established in 1944, is considered center or center-left; while LeFigaro, established in 1826 , is widely held to espouse the most conservative, or right-wing, voice of the three. This ideological diversity is an asset to the validity of our dataset.

The articles analyzed for this study were obtained by accessing the search engine of each of the three individual newspapers. The specific terms used to identify content-

\footnotetext{
${ }^{10}$ The study was confined to print media for practical reasons. We recognize the merits of broadcast media, and indeed there was television and internet coverage of this issue, but we did not include them in our study because of access limitations.
} 
appropriate articles were halal hamburgers and Quick. This search resulted in 79 articles (Libération, $\mathrm{n}=19 ;$ LeMonde, $\mathrm{n}=25 ;$ LeFigaro, $\mathrm{n}=35$ ). Only 76 of these articles were coded as three were found to be unrelated or only marginally related to the case. Thus, the total number of articles analyzed was 76, but given that some articles made multiple claims, we ended up with a total of 98 usable, appropriate claims.

One coder was used for the entire coding process, but validity was established at the onset with two readers coding a sample of the articles. In this stage, inter-coder reliability was established by sampling 20 percent of the database and coding them until both coders reached agreement on the claims 95 percent of the time. The remaining articles were coded by a single coder unless determination was too difficult, at which time both coders consulted each other for resolution. Such cases were determined via coder negotiation and consensus.

Our initial newspaper selection method identified the appropriate articles; our next step was to analyze qualitative claims to reveal the content of media frames and their frequency. This approach allowed us to gage the breadth of interpretation of halal hamburgers and to focus on meaning of the issue. Coding began with coders inductively extracting text that signaled a diagnosis of the halal hamburger experiment. In other words, the author constructed claims that signaled rationale for supporting or challenging Quick's halalburger decision. From the original 98 claims we were able to cluster them into six distinctive categories (discriminatory to non-Muslims, unrepublic, private interest, consumer choice, egalitarian, civic). Some of these categories share ideological tenets, therefore, we further clustered them into three primary interpretative frames that constitute the constellation of discursive meaning about halalburgers during this time period. While we feel comfortable in stating that this study represents well the public discourse in France over the Quick campaign, we insert the caveat that our findings apply to these three national media outlets alone. 


\section{Findings}

Our findings suggest that media framing of halalburgers is unsettled and contentious. The construction of multiple, competing frames of halalburgers goes beyond crafting meaning; it is also a vehicle in which symbolic boundaries are erected to differentiate foods and people (Bourdieu, 1984). In this way, the media aligns fast-food halalburgers with Islamic consumers, setting the course for food contests and legitimation battles. It is less clear that media discourse, provides resolution, or settles the battle over halal foods, but it gives us three distinct ways to think about the role of the halalburger in French culture. The media dispute consisted of six distinct categories of claims we have clustered into three frames: 1) republican ideal, 2) free-market, and 3) cultural diversity (see Table 1). Each frame amplifies in salience certain elements over others that distinguish it. Before proceeding to discuss frame content, it is instructive to note a general pattern. Most of the claims-making activity opposed the Quick campaign; fifty-nine percent $(n=58)$ of the claims challenged Quick's decision to add halalburgers to its menu, while forty-one percent $(n=40)$ supported the move ${ }^{11}$. The republican ideal frame is made up of claims challenging the decision and the free-market and cultural diversity frames lend support. However, the republican ideal frame consists of considerably more claims-making activity, therefore, we turn to a discussion of it first.

--- Table 1 about here ---

${ }^{11}$ When looking at the distribution of claims by newspaper origin, discourse within Libération and Le Figaro - the two newspapers the most ideologically distinct - is predominantly oppositional (for Libération, 58 percent oppositional claims, 42 percent supportive claims, for Le Figaro, 66 percent oppositional claims, 34 percent supportive claims). Le Monde is the only newspaper to show a more balanced distribution between oppositional and supportive claims (48.5 percent oppositional claims, 51.5 percent supportive claims). 


\subsection{The republican ideal frame}

Quick's decision to offer halalburgers was made public in December 2009 when a reporter leaked the corporate experiments quietly in process (Quick, 2010) and opposition ensued. The republican ideal frame marshaled two sets of claims: halalburgers are discriminatory to non-Muslims $(n=36)$ and unrepublic $(n=22)$. Most prevalent in this frame was the charge that the halal campaign discriminated against non-Muslim French citizens. Over one-third $(n=36)$ of all claims alleged discrimination on the grounds that the exclusivity of the new menu failed to accommodate the interests of non-Muslims whose preference is for non-halal meat. Recall that corporate trials concluded that both halal and non-halal production lines were not technically feasible. The republican ideal frame also challenged Quick's campaign on the grounds that it is unrepublic because it violates core tenets of French republican universalism. By tailoring the restaurant menu to religion practices, citizens are encouraged to consume based on their cultural membership, rather than as undifferentiated individuals entering the public sphere on equal footing. The following claims illustrate how the media wove accusations of discrimination together with 'us' vs. 'them' binaries, to frame the issue

We think that we should be tolerant. Those who want to eat halal should be able to do so and those who do not want to should also have their needs met.

No one would contest that a fast food chain should be able to sell halal or kosher hamburgers. The debate is about exclusivity.

[I am not] bothered that there is a halal offering, but it goes too far when [Quick] 
offers only halal; it then becomes discriminatory.

Such claims accentuate Quick's logistical decision to offer only halal meat, linking it to broader ideals of equity, tolerance, and inclusivity. For this frame, the initiative was troublesome because one group had been singled out for special services due to private religious attributes. Liberté, as conceptualized by French universalism, stipulates the right of citizens to exercise individual choice unconstrained by cultural or institutional influences. In this case, Quick's halal-only menu violates this premise denying non-Muslim customers (and potential customers) choice and institutionalizing differential treatment based on the private matter of religion.

Media claims-making typically developed a diagnosis of the problem - to articulate to the audience their view of the issue, yet some conveyed an assessment of who was to blame for Quick's decision. Islam and the state were the two most likely sources. "It is really the head of state which is in charge of this process of forced Islamization of France and the setting up of an Islamic tax. The state is collecting an Islamic tax", charged one critic. Recall that the primary stockholder of Quick is the state-owned organization, Caisse des Dépôts et des Consignes, which, for some, is a conflict of interest. This frame stressed that Quick's new menu had structured a practice whereby all Quick consumers are forced to financially support Islam. Quick profits are used to compensate halal certifiers of the meat, which are Muslim-run organizations. Another article articulated the situation this way: "If I go to this restaurant, I am obliged to participate against my will to the financing of Islamic organizations which give the halal certifications." Here not only is financial support of Islam highlighted, but so too is the issue of freedom.

With the use of terms like "Islam", "Islamization of France", or "Islamic tax", this frame bridged halalburgers to contemporary rhetoric known to inflame citizens. In this way, media claims-makers constructed halalburgers as a moral struggle between good (French 
republicanism) and bad (Islam). Liogier's (2012) argument that Islam has come to be seen as constituting a "collective paranoia" helps us understand the effectiveness of this strategy to align with readers.

The republican ideal frame also consisted of claims that moved beyond a critique of the issue based on discrimination to underscore what the media perceived to be under threat the French Republic itself. Such claims make up thirty-eight percent $(n=22)$ of the republican ideal frame. Claims that constitute this frame are exemplified in the following: "It would be better if at halal Quick restaurants we could also eat non-halal meat, if that is possible. But if that is not possible, [the situation] does not follow the foundations of the republic." Another opined that, "[t]he controversy around Quick...is symptomatic of a tendency to establish Islam as contrary to ideals of the Republic."

Other claims blended anxiety about the threat to republican ideals with concern for the segregationist tendencies that were perceived to accompany the new menu. "[Quick restaurants] were welcoming places of diversity. Today, they are reserved for the Muslim population," according to one. Another argued, [Quick's halal experiment] "leads to communitarianism which is opposed to republican ideals." Recently, public discourse in France has appropriated the term communitarianism with many using it pejoratively to label a group, or act as 'ghetto', or isolationist. To classify a group as communitarian is to note their refusal to take part in mainstream culture. Rather than interpret the absence of halal offerings as exclusionary for Muslims, this claim articulates Quick's action to add halal to their menu as exclusionary for non-Muslims.

It might be easy to conclude that French republican ideals are topics of concern to academics or constitutionalists, but this frame demonstrates that citizens remain committed to these principles.

But Quick is French isn't it? So here is a western restaurant making a turn towards 
religious food. It bothers me. As for me, even though I am Catholic, I also believe in laïcité. But, I don't bring my religious beliefs into the restaurant. It is a change symbolizing well the time period in which we live... Islam is taking more importance in our lives and more and more room in our daily practices without our permission. This claim appears to accentuate a number of problematic components to Quick's menu diversification. The mounting role of Islam in French life is foregrounded in this claim as is the pace of change. The lack of control some experience over the process is also noticeable when the author speaks of "permission". For this claims-maker, a sense of loss is palpable, but more importantly, this claim emphasizes the penetration of private matters in public life, upsetting traditional republican ideals.

The republican ideal frame shows us that media framing of halalburgers as exclusive treatment of one cultural group over others and a threat to the tenets of republican universalism were reoccurring themes constructed to encourage an understanding of halalburgers as a worrisome condition for all French citizens. Even though this frame provides evidence of the continuity of republican ideals in contemporary French society, it is not without its challengers. Just as this frame condemned halalburgers in defense of republicanism, others supported the making of cultural distinctions.

\subsection{Free-market frame}

As noted earlier, forty-one percent $(n=40)$ of all claims offered support for the Quick campaign, but they did so for different reasons. The media framed support by marshaling arguments for the free-market and cultural diversity. The most prevalent of these two - the free-market - received twenty-eight percent $(n=27)$ of all claims. The free-market frame was most frequently articulated to advocate for an inclusive menu in the name of laissez-faire capitalism. Central to this perspective is the role of consumer choice and private interests to explain Quick's halal campaign - both the calling cards of laissez-faire capitalism. 
The free-market frame argues that failure to respond to consumer choice is undesirable because it interferes with the accumulation of capital. In this frame, it is the market, or business, which must be unrestrained, not people. The free-market frame tends toward promoting menu diversification to serve a greater clientele to maximize profits. Menu diversification is less likely valued as a tool for cultural integration or social justice, rather a halal menu is valued for its ability to turn Muslims citizens into capitalist consumers.

Like the republican ideal frame, media deploying this frame distinguished public from private interests, but rather than shielding the public sphere from cultural diversity, this frame punctuated the ability of business to act in their best interest, unfettered by state interventions. Dietary accommodation, or equitable treatment of Muslim consumers, is advocated as a means to an end - to robust market economies.

Eleven percent $(n=11)$ of the media claims applauded the halal campaign on the basis that it was in the best interest of Quick - a private corporation. Owing to the principles of laissez-faire capitalism, Quick was entitled to design profit maximizing practices without interference from the public sector. The following claims exemplify the place of private interest in the free-market frame.

[The debate over Quick] confuses communitarianism with diversity. Quick is not a public service. We are definitely talking about a private company that wants to take advantage of a market to do business.

Quick is a private enterprise which can do whatever it wants with its offer [menu]. Nobody is obliged to go and eat at Quick. 
Honestly, it is the freedom to do business. Is there a problem with that? The problem is located in the discourse as it has been articulated the past few months in France which is to systematically stigmatize the Muslim religion or immigration in France.

By distinguishing "public service", "private enterprise", and "communitarianism", this freemarket frame sets up distinct rules for market activity, which begin by locating Quick in the private sector, far from the authority of republican ideals. This is a liberating tactic to free media claims-makers to bridge halalburgers to prevailing market ideology which condones such unfettered business practices. These constructs of 'public' and 'private' are ideals, however. No recognition was made of the ownership arrangement - that Quick was not solely a private entity, but partly owned by the state through its majority stakeholder status through Caisse des Dépôts et des Consignations.

The media also defended the halal menu on the grounds that consumer choice was preserved. Sixteen percent $(n=16)$ of the claims supported the new menu based on consumer responsiveness. The following claims illustrate this rationale.

From the last I know Quick is not a public service... we speak here about private enterprise which wants to occupy a market to do business....there is nothing discriminatory in this issue: consumers can choose their menu and [if they do not want halal] they can choose fish.

This choice simply results from the meeting between supply and demand, as well as a marketing choice. Whether this choice answers a demand based on a particular taste, on the success of a foreign dish, or on a cultural or religious tradition, it all goes back to free enterprise.

The free-market frame makes clear that Quick's decision is justified because it is in keeping with other cultural values rooted in the fundamental tenets of laissez-faire capitalism. 
Quick's campaign is in keeping with demand/supply logic whereby rational and utility maximizing consumers are unencumbered in the search to realize their preferences. Menus are matters of the market - therefore, private and not topics by which others should seek to influence with public sector ideals. No discussion was provided of the economic and social factors which influence consumption, or choice.

\subsection{Cultural diversity frame}

Although weakly represented, some media claims were directed toward valorizing equity, tolerance, and inclusivity as well as a recognition for the role halal fast food can play in advancing cultural integration. Thirteen percent $(n=13)$ of all claims constitute the cultural diversity frame. Advocates of this frame are nearly in direct opposition to many of the claims made by the republican ideal frame. These claims suggest that the halal menu is inclusive and empowering, but can also generate a sense of belonging and attachment to promote integration. The cultural diversity frame assumes that restaurants which fail to accommodate the dietary preferences of Islamic consumers are discriminatory and reproduce inhospitable public spaces. By promoting a standard menu prepared by non-halal methods, it is unfair treatment of French Muslims and aids in segregation. Non-halal menus deprive Muslims of opportunities to fully participate in society, forcing them to self-segregate in order to obey religious teachings of their faith. Claims were also made to suggest that Muslims are denied the opportunity to exercise personal choice, unlike other non-Muslim French citizens.

The cultural diversity frame advocates for restaurants to assure equitable treatment of all religious groups by accommodating their dietary needs and welcoming diversity, rather than reproducing a culturally undifferentiated menu. One customer praised Quick for its inclusivity, "Quick assures a diverse menu that permits its clients to consume according to their personal choice, without exclusion and in complete transparency. Another added, "Nothing is forbidden to us [Muslims] now." 
Whereas halalburgers are good for business, from the perspective of the free-market frame, the cultural diversity frame views them as tools for personal well-being. Some claims drew out the psychological implications of the new menu. "The young Muslim population...expresses an undeniable feeling of satisfaction due to this acknowledgement of their cultural and religious identity." Boundaries which are redrawn to not only include, but to accommodate differences, signal a cultural code for attachment and belongingness (Swidler, 2001). This suggests that fast-food can aid in reformulating the self.

The cultural diversity frame also went further to make the case that halalburgers add value to society by inspiring cultural integration. "The first time, we had cakes and we left. It was not yet halal. It would be like eating during Lent. It's not possible," but now we can take advantage of this opportunity. Whether it is out of preference, convenience, or curiosity halal Quicks appear to offer Muslims a new set of dining options. Young Muslims are particularly drawn to the restaurant because it allows them to meld their religious rites to contemporary lifestyle practices. The feeling of welcome is also significant for girls. One reporter claimed that, "[b]efore, girls where not coming in [the Quick] restaurant [which was] mainly patronized by young men. Now, the Muslim clientele comes with its family: parents, children and grandparents."

sum, the cultural diversity, while much less prevalent than the two other competing frames, shows us that media framing does not have to be oppositional as in the case of the republican ideal frame, nor does it have to be supportive for reasons of instrumental market logic. Although indirectly stated, a small minority of media claims-makers framed the halal menu as one with liberatory potential to accentuate positive social value. This frame assumes a preference for a public sphere that utilizes food to inspire bonds of commonality to accommodate Muslims religious differences, which in turn would result in improved sociocultural integration. From this perspective, private traits, recognized and accommodated in 
the public sphere, may engender social relations which serve the national good. In this way, the Quick halalburger is civic. By offering halalburgers, "halal Quicks" are structured in such a way as to turn individual Muslim consumers into French citizens.

\section{Discussion}

\subsection{Bridging burgers}

This research shows that media framing of halalburgers is unsettled, suggesting that coverage in France between 2009-2010 is emblematic of a dynamic culture as competing frames were constructed to align with dominant, yet competing societal values. Through the use of frame bridging (Snow, Rochford, Worden, Benford, 1986), the media was able to link halalburgers to ideologically compatible, but structurally disconnected frames. In this way, the media played a significant role in shaping gastronationalism.

Our analysis reveals that media frames linked halalburgers to long-held ideals representative of French republicanism, the free-market, and cultural diversity. The presence of frame dissensus, however, is expected in a democratic society. Although the free-market and cultural diversity hold some sway, republican universalism remains highly valorized as evidenced by the quantitative predominance of claims opposing halalburgers. Also, it is significant to note that although the free-market frame supported the halalburger, it did so only to achieve instrumental market ends. This leaves us only with the cultural diversity frame which was imbued with claims of inclusivity and equality, but yet only represented by a bit more than one-tenth of all claims. For these reasons, we conclude that the frame dispute was less about halalburgers - or the free-market or cultural diversity - than it was about the meaning of French identity, including the parameters which legitimate claims to citizenship. In short, fast-food burgers became a vehicle to reassert Frenchness by enrolling Quick's halal menu to facilitate the drawing of nationalist boundaries.

Efforts to preserve traditional tenets of republicanism are explicit in many media 
claims which define halalburgers as a violation of laïcité. In attempting to link Quick's decision to republican universal ideals, frame bridging presents the impact of Quick's new menu as critical to the very future of the French Republic. The use of terms like "Islamization", “discriminatory", “exclusivity", and "free choice” were instrumentally used to draw parallels between burgers and universalist principles of égalité and liberté. When the media framed Quick as a former "welcoming place of diversity" now reserved for Muslims, threats to fraternité and fears of segregationist communitarianism were foregrounded.

Also of significance is the bridging practices adopted by the media which may stifle change. Frames were more likely to bridge burgers with pre-existing French values thereby obscuring alternative ways of conceptualizing the role of halal burgers in modern society. As a result, bridging as a discursive strategy affects the potential for meaningful deliberation with the public about the proper place of religion in society as well as the type of society to which French citizens aspire. This practice challenges the role of the media to fulfill its function as a conduit for democratic engagement.

By punctuating the halal case with claims of discrimination and threats to the republic, the media attempt to move the discourse from that of interest to a handful of fast food patrons to one which touches each French citizen, regardless of whether or not they patronize Quick. In such discourse, halalburgers become symbolic code for the slippery slope of postmodern relativism brought about by cultural diversity, a threat intended to rally the masses in support of traditional nationalist attachments. This raises the question of the exceptionalism of halal and Islamic foodways. Would we have witnessed the same frame dispute if Polish pirogies or Mexican tamales had been proposed to the Quick menu?

Given the "Islamization of France" discourse that has gripped the nation in the past decade or so (Delphy, 2006; Lamont, 2002; Liogier, 2012), it becomes evident that media frames were constructed to align with broader cultural forces, such as the "collective 
paranoia" which Liogier (2012) describes. As a consequence of the national anxiety around Islam - typified by adherents who bemoan the end of an era or fear further cultural decline on the world stage - bridging food, or any element of social life for that matter, to the fear of Islam, is likely to gain traction. Given France's culinary status as the global gold standard (Ferguson, 1998; Martigny, 2010), it is not surprising that perceived threats to the foodways of the French would be met with opposition, even fast-food. If gastronomy in France is sacred, the kitchen might well be the first line of defense in a battle over identity, even if that kitchen is stocked with hamburger patties rather than foie gras.

It is also notable that the meaning of Frenchness when applied to the Quick corporation was rarely interrogated by the media. It appears Quick is only French because it was purchased by a French entity - Qualium Investissement - in 2007, a little more than two years prior to this public debate. Quick began as a Belgium operation and, although it moved into France in the early 1980s, it retained Belgium ownership throughout this time. The failure of most of the media to dissect the ownership of the firm suggests the adoption of an uncritical stance toward the issue. Whether the media intentionally bridged fast-food with issues of republican ideals or participated in an unconscious cultural reproduction of this alignment is out of the scope of this paper. The outcome, however, is that most of the framing activity advanced by the media had the effect of linking food to ideals of republicanism and cultural integration, in this way, the media used their platform to advocate for the defense of republican universalism and to point the finger of blame on Islamic forces deemed to be inciting broader political breakdown.

\subsection{Gastronationalism on the home front and in the everyday}

While dominant, alignment with republican ideals did not go uncontested; others bridged the halal campaign to the free-market and cultural diversity. This framing dispute demonstrates the process by which gastronationalism is constructed, resisted, and negotiated. 
DeSoucey (2010, p. 434) argues that gastronationalism unites "otherwise geographically, socially, and political divided populations", yet, when examined within the national context, we found not unity, but dissensus. Revealed in the media frames are tensions that can emerge within national boundaries as the meaning of legitimate foods and foodways become the battle ground for identity. In this way, gastronationalism can obfuscate socio-cultural and political divisions within a nation as minority populations are denied access to their traditional foods or foodways, opting instead to valorize traditional institutional forms that segregate and deny Islamic followers their foods as well as a sentiment d'appartenance (a sense of belonging). This may have unintended consequences. Delphy (2010) argues that such cultural deprivation by dominant groups may encourage further efforts on the part of the oppressed to segregate themselves in their quest to find a sense of belonging. Our finding that young Muslims express a sense of belonging from the new halal menu adds support to Delphy's argument.

In articulating halal food as a violation of republican ideals, such media frames are part and parcel of how gastronationalism gets [re]constructed and legitimated in daily life. Yet the narrow script of Frenchness gets written into identity discourse and marginalizes any competing narrative only by [temporarily] dominating the framing dispute. Our case shows that tension persists and gastronationalism must not only field confrontations abroad to preserve culinary cultures, but it must also continually wage battle at home with those who seek to challenge it, including the media. Through the resistance of halal food, along with advocacy to preserve the [fast-food] status quo, gastronationalism functions as a tool to preserve French identity, yet this is a tenuious hold. Given the growing Muslim population, we can expect repeated challenges to gastronationalism. In February of 2012, a national television broadcast revealed that all slaughterhouses in the Paris metropolitan area were processing all meat according to halal standards. Many were shocked to learn that they had 
been unwittingly consuming halal certified meat. Some continued to portray this situation as further evidence of the "stealth Islamization of the French food chain" (Soeren, 2012).

Whether it is resistance to local slaughterhouse practices, halal foods in school lunches, or on hospital menus, gastronationalism continues to be under scrutiny and negotiated in contemporary France.

Moreover, DeSoucey $(2010,448)$ argues that "gastronationalism buttresses national identity against perceived threats from outsiders who wish to eliminate certain objects or practices," adding “an important layer to gastronationalism's role in creating cultural market and political protections" [emphasis added]. Our findings show that the cultural authority of gastronationalism is undergirded in its ability to challenge those who seek, not to eliminate, but to add new foods or practices. What's more, the traditional culinary repertoire is not confined to haute cuisine, but includes everyday foods which are politically enrolled to reproduce both French gastronomy and citizenship. This is particularly informative given that it is fast-food that has historically bore the brunt of criticism for diluting French culinary excellence (Steinberger, 2009) and perpetuating the Americanization of French culture. When faced with challenges from Islam, it appears that the classic fast-food menu is not the enemy, but worthy of protection when it can be framed in defense of widely acclaimed political virtues. This raises the question for future consideration, is fast-food now a part of the French culinary repertoire? Perhaps more accurately, how is the French culinary repertoire stratified?

\subsection{Defensive gastronationalism}

If we understand the media's framing of Quick's halalburger as emblematic of the perpetuation of the myth of the "Islamization of France" it becomes evident that gastronationalism can be used as a political weapon laden with nativist and defensive tendencies that intentionally erect boundaries to distinguish ingroups from outgroups. While 
the role of gastronationalism is to preserve heritage and cultures on a pan-nationalist stage, when articulated on the national front, it becomes a tool for maintaining exclusivity and quieting challengers, rather than the protection of a globally-recognized cultural asset. This suggests that the media play a significant role reproducing gastronationalism. Its role is not unidirectional, but multifaceted, and in this dissensus, the media erect boundaries to distinguish national sentiments and foods.

Others have critiqued the defensive properties embodied in contemporary efforts at food system localization (DuPuis and Goodman, 2005; Hinrichs, 2000; 2003; Sage, 2001; Winter, 2003), and, in much the same way, we see the halal frame dispute as form of defensive gastronationalism. Defensive gastronationalism does not necessarily function to solely protect national treasures, such as long-cherished foods and foodways, but can prompt contradictory and exclusionary tendencies by affirming ethnic boundaries which segregate and stratify. For instance, few French citizens would argue that the modern fast-food menu is worthy of cultural protection, yet this was the consequence of this frame dispute. The halal case shows that gastronationalism can become defensive when it is enrolled as a political project to protect a way of life and civilization perceived to be under threat from internal demographic or social changes, such as the mythical "Islamization of France". In this way, gastronationalism envelops contradictions when, in the name of cultural protection, it trades on divisive ideals that exclude possibilities for full participation in society.

\section{Conclusion}

We have employed framing concepts to conceptually clarify the substantive ideological themes that formed the media discourse surrounding the French halalburger controversy, finding that frames were constructed in such a manner to bridge broader principles which resonate with the French public. We discovered that the media's response was one imbued with tension as frames attempted to map onto cultural ideals related both to 
French republican ideals, the free-market, and cultural diversity. We have argued that it is useful to see opposition to fast-food halalburgers as an instance of defensive gastronationalism. When faced with the perception of national threat, not only can haute cuisine be enrolled in gastronationalism, but fast-food can also be marshaled to protect national identity as the media draw boundaries to advocate for the defensive or exclusionary roles which perpetuates divisions. This was accomplished by condemning Quick for violating the secular principles underlying republican universalism through their introduction of religious distinctions into the public sphere, in this way, defying traditional principles of liberté, égalité, and fraternité.

Such linkage between food and identity as a cultural talisman for maintaining rigid definitions of inclusion and access in the face of increasing diversity suggests a need to explore other ways that food is enrolled to discipline populations perceived as threatening. Tropes for non-halal foods in fast-food and public schools and restrictions against traditional dress make clear that diversity will continue to be challenged in France. Whether this response is emblematic of a country faced with the reality of socio-cultural and political decline is out of the range of this discussion, but it nonetheless ignites possibilities for future scholarship. More research is needed into the ways defensive gastronationalism exacerbates a number of socio-cultural tensions linked to religion, race, ethnicity, gender, and social class.

This paper has attempted to extend DeSoucey's conception of gastronationalism, while simultaneously advancing an understanding of the media's resistance to Quick's halalburger experiment. To what extent is the media's response to halalburgers unique? Might we expect the ideological themes undergirding defensive gastronationalism to manifest themself in other cases where food is under fire? In France or in other parts of the world? By amplifying divisiveness and exclusivity, defensive gastronationalism challenges literature extolling an increasing trend toward food system democratization (Hassanein, 2003). 
Although challengers to halalburgers out-numbered supportors in this study, one should not lose sight of the tension between these frames suggesting both the dynamism of French culture and its culinary palate. The conflict over halalburgers demonstrates that not only is the future of French cuisine open for reconsideration (Martigny, 2010), it is this dynamism that holds the potential for a new culinary repertoire which may yet include a democratic promise. Case studies may be able to address how actors use frames to build culinary bridges and extend the democratic franchise - while also preserving cultural heritage - or how frames amplify difference and divide people based on their foods and foodways.

\section{Acknowledgements}

The authors would like to thank Lindsay Way for her assistance in data collection on this research. We also extend our gratitude to Patrick H. Mooney and Craig Harris for their insightful comments on earlier drafts of this document as well as to three rigorous reviewers whose insights greatly improved this manuscript. Presentations of this data were given at the Centre International d'Études Supérieures en Sciences Agronomiques (SupAgro), Michigan State University, and the 2012 International Sociological Association annual meeting. We are indebted to the feedback of the audience members which helped us fine tune our analysis. Funding for this research was supported by the Institut National Polytechnique of Toulouse, France, through a Soutien Mobilité Internationale grant and Michigan AgBioResearch. 


\section{References}

Akan, M., 2009. Laïcité and multiculturalism: The Stasi report in context. British Journal of Sociology 60, 2, pp. 237-256.

Allison, A., 1997. Japanese mothers and obentōs: The lunch box as ideological state apparatus. In: Counihan, C. and Van Esterik, P., Editors, 1997. Culture and food: A reader, Routledge, New York.

Béland, D., 2003. Identity politics and French republicanism. Society 40, 5, pp. 66-71.

Belasco, W., and Scranton, P., 2002. Food nations: Selling tastes in consumer societies. Routledge, New York.

Bell, D. and Valentine, G., 1997. Consuming Geographies: We are where we eat. Routledge, London.

Bereni, L., 2007. French feminists renegotiate republican universalism: The gender parity campaign. French Politics 5, pp. 191-209.

Bergeaud-Blackler, F., 2001. La viande halal peut-elle financer le culte musulman? Journal des Anthropologues 84, pp. 145-171.

Bergeaud-Blackler, F., 2005. De la viande halal à l'halal food : comment le halal s'est développé en France ? Revue Européenne des Migrations Internationales 21, pp. 125-147.

Bergeaud-Blackler, F., 2006. Halal : d'une norme communautaire à une norme institutionnelle. Journal des Anthropologues 106-107, pp. 73-103.

Bertossi, C., 2012. The performativity of colour blindness: Race politics and immigrant integration in France, 1980-2012. Patterns of Prejudice 46, 5, pp. 427-444.

Boisard, P., 2003. Camembert: A national myth. University of California Press, Berkeley.

Bonnafous, S. 1991. L'immigration prise aux mots. Éditions Kimé, Paris.

Bourdieu, P., 1984. Distinctions: A social critique of the judgment of taste. Harvard University Press, Boston.

Bordo, S. 1997. Anorexia nervosa: Psychopathology as the crystallization of culture. In: Counihan, C. and Van Esterik, P., Editors, 1997. Culture and food: A reader, Routledge, New York. 
Bowles, B., 1995. La République régionale: Stade occulté de la synthèse républicaine. The French Review 69, 1, pp. 103-117.

Bynum, C. W., 1997. Fast, feast, and flesh: The religious significance of food to medieval women. In: Counihan, C. and Van Esterik, P., Editors, 1997. Culture and food: A reader, Routledge, New York.

Caisse des Dépôts et des Consignations, 2012. Corporate web page. Retrieved November 12, 2012. Available at: http://www.ltic.org/Caisse-des-Depots-et-Consignations.html.

Campbell, H., Murcott, A. and MacKenzie, A., 2011. Kosher in New York City, halal in Aquitaine: Challenging the relationship between neoliberalism and food auditing. Agriculture and Human Values 28, pp. 67-79.

Cohen, B., 1963. The press and foreign policy. Princeton University, Princeton.

Counihan, C. M. , 2002. Food in the USA: A reader. Routledge, New York.

Counihan, C. M. and Van Esterik, P., 1997. Food and culture: A reader. Routledge, New York.

Delphy, C., 2006. Antisexisme ou Antiracisme ? Un faux dilemme. Nouvelles Questions Féministe 25, 1, pp. 59-83.

Delphy, C., 2010. Classer, dominer : qui sont les autres ? Éditions La Fabriques, Paris.

DeSoucey, M., 2010. Gastronationalism: Food traditions and authenticity: Politics in the European Union. American Sociological Review 75, pp. 432-455.

DuPuis, M. and Goodman, D., 2005. Should we go home to eat: Toward a reflexive politics of localism. Journal of Rural Studies 21, pp. 359-271.

Fantasia, R., 1995. Fast food in France. Theory and Society, 24, pp. 201-243.

Ferguson, P.P., 1998. A cultural field in the making: Gastronomy in $19^{\text {th }}$-century France. American Journal of Sociology, 104, pp. 597-641.

Fraisse, G., 1989. Muse de la raison, démocratie et exclusion des femmes en France. Aix enProvence, Alinéa.

Gabaccia, D. R., 1998. We are what we eat: Ethnic food and the making of Americans. Harvard University Press, Cambridge. 
Gamson, W.A. and Modigliani, A., 1987. The changing cultural affirmative action. In: Braungart, R.G. and Braungart, M.M., Editors, 1987. Research in Political Sociology, JAI Press, Greenwich.

Gamson, W.A., 1992. Talking Politics. Cambridge University Press, New York.

Gastwirt, H., 1974. Fraud, corruption, and holiness: The controversy over the supervision of Jewish dietary practice in New York City, 1881-1940. Kennikat, Port Washington.

Gitlin, T., 1980. The Whole World Is Watching. University of California Press, Berkeley.

Goody, J., 1997. Industrial food: Towards the development of a world cuisine. In:

Counihan, C. and Van Esterik, P., Editors, 1997. Culture and food: A reader, Routledge, New York.

Goffman, E., 1974. Frame Analysis: An Essay on the Organization of Experience. Harvard University Press, Cambridge.

Gordon, P. and Meunier, S., 2001. Globalization and French cultural identity. French Politics, Culture and Society 19, pp. 23-41.

Hassanein, N., 2003. Practicing food democracy: A pragmatic politics of transformation. Journal of Rural Studies 19, 1, pp. 77-86.

Hinrichs, C.C., 2000. Embeddedness and local food systems: Notes on two types of direct agricultural markets. Journal of Rural Studies 16, pp. 295-303.

Hinrichs, C.C., 2003. The practice and politics of food system localization. Journal of Rural Studies 19, pp. 33-45.

Iyenga, S., 1990. The accessibility bias in politics: television news and public opinion. International Journal of Public Opinion Research 2, pp. 1-15.

Jennings, J., 2000. Citizenship, republicanism and multiculturalism in contemporary France. British Journal of Political Science 30, 4, pp. 575-87.

Johnstone, C., 2008. (Post-)queer citizenship in contemporary republican France. Contemporary French and Francophone Studies 12, pp. 89-97.

Jugé, T. and Perez, M., 2006. The modern colonial politics of citizenship and whiteness in France. Social Identities 12, pp. 187-212.

Kendall, D. 2011. Framing Class: Media Representations of Wealth and Poverty in America. Rowman and Littlefield, Lanham. 
Kahn, K.F., and Kenney, P.J., 2002. The Slant of the News: How Editorial Endorsements Influence Campaign Coverage and Citizens' Views of Candidates. American Political Science Review 96, pp. 381-94.

Kitzinger, J. and Reilly, J., 1997. The rise and fall of risk reporting. The European Joumal of Communication, 12, pp. 319-350

Laborde, C., 2001. The culture(s) of the republic: Nationalism and multiculturalism in France. Political Theory 29, pp. 716-735.

Lamont, M., 2002. Particular universalisms: North African immigrants respond to French racism. Ethnic and Racial Studies 25, 3, pp.390-414.

Lamont, M., 2004. Immigration and the salience of racial boundaries among French Workers. In: Chapman, $\mathrm{H}$ and Frader, L.L., Editors, 2004. Race in France: Interdisciplinary perspective on the politics of difference. Berghahn Books, New York.

Landes, J.B., 1988. Women and the public sphere in the age of the French revolution. Cornell University Press, Ithaca.

Levenstein, H., 1988. Revolution at the table: The transformation of the American diet. Oxford University Press, New York.

Lever, J and Miele, M., 2012. The growth of halal meat markets in Europe: An explorationof the supply side theory of religion. Journal of Rural Studies 28, 4, pp. 528-537.

http://dx.doi.org/10.1016/j.jrurstud.2012.06.004.

Liogier, R., 2012. Le mythe de l'islamisation: Essai sur une obsession collective. Edition du Seuil, Paris.

Marquand, R., 2010. Burqas ?: No, Bacon Burgers are France's New Cultural Battleground. Christian Science Monitor. Retrieved September 2, 2012. Available at : http://csmonitor.com/World/Europe/2010/0218/Burqas-No-bacon-burgers-areFrance-s-new-cultural-battleground.

Martigny, V., 2010. Le goût des nôtres : gastronomie et sentiment national en France. Raisons politiques 37, pp. 39-52.

Mennell, S., 1985. All manners of food: Eating and taste in England and France from the middle ages to the present. Blackwell, Oxford.

Mennell, S., 1997. On the civilizing appetite. In: Counihan, C. and Van Esterik, P., Editors, 1997. Culture and food: A reader, Routledge, New York.

Mintz, S., 1986. Sweetness and power: The place of sugar in modern history. Penguin Books, New York.

Mintz, S. and Du Bois, C., 2002. The anthropology of food and eating. Annual Review of Anthropology 31, pp. 99-119.

Pommier, A. H., 2009. Quick teste discrètement son burger halal. Le Figaro. Retrieved 
November 28, 2012. Available at : http://www.lefigaro.fr/conso/2009/12/16/0500720091216ARTFIG00520-quick-teste-discretement-son-burger-halal-.php.

Poulain, J.P., 2002. Sociologie de l'Alimentation. Presses Universitaires de France, Paris.

Poulain, J.P., 2008. Manger aujourd'hui : Attitudes, normes et pratiques. Privat, Bouloc.

Quick, 2010. Bilan du test de venter d'une gamme de produits à base de diande halal.

Company press release. Retrieved November 2, 2012. Available at:

http://groupe.quick.fr/fr/le-groupe/bilan-du-test-de-vente-de-produits-base-de-viande-halal.

Roy, O., 2005. La laïcité face à l’Islam. Editions Stock, Paris.

Roy, O., 2007. Liberté, Egalité, Laïcité. The American Interest, pp. 126-131.

Sage, C., 2001. Social embeddedness and relations of regard: Alternative food networks in southwest Ireland. Journal of Rural Studies 19, pp. 47-60.

Schnapper, D., 2010. Peut-on encore être universaliste ? In : Trigano, S., Editor, 2010. L'universel et la politique des identités, Editions de l'Eclat, Paris.

Scheufele, D. 1999. Framing as a theory of media effects. Journal of Communication 49, pp. 103-122.

Scholliers, P., 2001. Food, drink and identity: Cooking, eating and drinking in Europe since the middle ages. Berg, Oxford.

Scott, J.W., 1996. Only paradoxes to offer: French feminists and the rights of man. Harvard University Press, Cambridge.

Scott, J.W., 2004. French universalism in the nineties. Differences: A Journal of Feminist Cultural Studies 15, pp. 32-53.

Seelow, P. S., 2010. Les hamburgers halal de Quick passent mal. LeMonde. Retrieved September 2, 2012. Available at http://www.lemonde.fr/societe/article/2010/02/17/ Quick-teste-les-hamburgers-halal-dans-huit-restaurants_1307527_3224.html.

Soeren, K., 2012. France goes halal. The Gatestone Institute. Retrieved November 20, 2012. Available at: http://www.gatestoneinstitute.org/2886/france-halal

Snow, D.A., Rochford, E.B., Worden, S.K., Benford, R.B., 1986. Frame alignment processes, micromobilization, and movement participation. American Sociological Review 51, pp. 464-481.

Spector, M., and Kitsuse, J.I., 1977. Constructing Social Problems. Cummings, Menlo Park. Steinberger, M., 2009. Au revoir to all that : The rise and fall of French cuisine. Bloomsbury Publishing, New York. 
Swedish Trade Council., 2009. Market analysis : France. Retrieved November 8, 2012. Available at $\therefore$ http://www.swedishtrade.se/PageFiles/158896/Food\%20from\%20 Sweden $\% 20$ France 520Final.pdf ?epslanguage $=$ sv.

Tebben, M., 2008. French food texts and national identity: Consommé, cheese soufflé, francité. In: Magid, A, M., Editor, 2008. You Are What You Eat: Literary Probes into the Palate, Cambridge Scholars Publishing, Newcastle.

Van Esterik, P., 1997. The politics of breastfeeding. In Counihan, C.A. and Van Esterik,P., Editors, 1997. Food and Culture: A Reader. Routledge Press, New York.

Watson J.L., and Caldwell, M. L., 2005. The cultural politics of food and eating: A reader. Blackwell, New York.

Winter, M., 2003. Embeddedness, the new food economy and defensive localism. Journal of Rural Studies 19, pp. 23-32.

Wright, W., and Reid, T., 2010 Green dreams or pipe dreams?: Media framing of the U.S. biofuels movement. Biomass and Bioenergy 35, pp. 1390-1399. 